\title{
MANIFESTASI SUATU TENAGA BARU: PERANAN KERAJAAN \\ DALAM MEMBANGUNKAN KEMUDAHAN BEKALAN ELEKTRIK
}

\section{Mohamad Khairul Anuar Bin Mohd Rosli \\ Ahmad Kamal Ariffin Bin Mohd Rus}

\begin{abstract}
An interesting development in the history of the Federated Malay States (FMS) concerns the production and supply of electricity power. It was widely considered as a new source of energy to meet the electrical needs of both economic sectors and the general public. The supply of electrical utility in the federation commenced at the end of the $19^{\text {th }}$ century, but its significant growth only really began with the involvement of government and, to some extent, private companies. This article, thus, discusses the development of electric supply facility in the FMS, up to the year 1941, so as to evaluate the extent to which the government had played influential roles in that regard. By perusing a wide range of primary sources such as the Colonial Office Records (C.Os. 273, 576 and 716, particularly), state government files and annual reports, there are substantial evidences to suggest that both entities - private companies and the government - did play vital roles in providing electric supply to a variety of customers in the polity. Private agencies attempted and managed to build power plants mainly to facilitate mining activities in certain areas. The government, on the other hand,also had major electric manufactories constructed. But it quickly gained commanding voice in the industry with the formulation of electricity legislatures and importantly, the establishment of the Electrical Department. This department had enabled a much wider and more comprehensive electricity supply, unlike private agencies which were only able to cover limited areas. All of these clearly show the more prominent roles of the government in matters relating to the supply of electricity in the FMS.
\end{abstract}

\section{Pengenalan}

Pada abad ke-20, Negeri-negeri Melayu Bersekutu (NNMB) memperlihatkan suatu perkembangan sejarah yang penting iaitu kemajuan kemudahan bekalan elektrik. Kemunculannya sebagai satu sumber tenaga yang baru membuatkan segenap aspek kehidupan dan pembangunan mula terpisah dari era sebelumnya. Jika dibandingkan dengan keadaan sebelumnya, masyarakat bergantung sepenuhnya kepada tenaga manusia untuk menjalankan kegiatan ekonomi. Keadaan ini membuatkan sesuatu aktiviti itu memerlukan tenaga kerja yang ramai selain mengambil masa yang panjang. Begitu juga halnya dengan kehidupan seharian yang bergantung kepada pelita, dapur kayu dan sebagainya. Namun dengan adanya bekalan elektrik kesemua aktiviti telah dipermudahkan dengan penggunaan jentera dan pekakas elektrik.

Melihat kepada perkembangan kemudahan bekalan elektrik, jelas sekali ia mempunyai perkaitan yang sangat rapat dengan NNMB. Jika ditinjau dari sudut sejarah, kemunculan bekalan elektrik di Tanah Melayu bermula di NNMB. Bekalan elektrik buat pertama kali digunakan pada tahun 1894 oleh Loke Yew dan Thamboosamy Pillai untuk kegunaan peralatan mengepam air di lombong bijih timah milik mereka di Rawang, Selangor.Selain itu, perkaitan bekalan elektrik dengan NNMB juga dilihat menerusi faktor ekonomi khususnya sektor perlombongan. Perkembangan aktiviti perlombongan bijih timah di NNMB 
terutamanya di Perak dan Selangor menjadi pemangkin kepada pembangunan kemudahan bekalan elektrik. Justeru, tidak hairanlah kedua-dua negeri tersebut mencatatkan penggunaan bekalan elektrik yang lebih tinggi berbanding Pahang dan Negeri Sembilan. Sejak mula ia digunakan sehingga menjelang Perang Dunia Kedua, pelbagai usaha telah dilakukan untuk memastikan kemudahan tersebut dapat dibangunkan dan seterusnya memberi manfaat kepada pengguna dan juga proses pembangunan di NNMB.

\section{Peranan Kerajaan}

Memandangkan bekalan elektrik merupakan satu sumber tenaga yang baru dan asing sama sekali dengan NNMB, maka pihak kerajaan memainkan peranan yang begitu signifikan dalam penyediaannya. Bagi pihak kerajaan penyediaan kemudahan asas ini merupakan obligasi sosial. Sehubungan dengan itu, pihak kerajaan telah mengambil langkah yang efektif dengan menubuhkan jabatan khusus untuk menguruskan pembangunannya. Sehingga tahun 1940-an, terdapat dua buah jabatan yang ditubuhkan oleh kerajaan iaitu Electrical Board dan Electrical Department masing-masing pada tahun 1921 dan 1927. Penubuhan jabatan ini penting sebagai agen yang menyelaraskan perkhidmatan di keempat-empat negeri berkenaan selain memusatkannya di bawah satu pengurusan.

Sebelum tahun 1920-an, tanggungjawab menyediakan bekalan elektrik dilaksanakan oleh Jabatan Kerja Raya (Public Works Department/PWD). Didapati dalam tempoh tersebut hanya PWD Selangor sahaja yang memainkan peranan membangunkan kemudahan bekalan elektrik khususnya di Kuala Lumpur. Kakitangan PWD dari Kuala Lumpur juga turut merangka skim pembekalan elektrik untuk Seremban, Negeri Sembilan tetapi tugas untuk membangunkannya diserahkan kepada syarikat swasta. ${ }^{1}$ Sebaliknya di Perak dan Pahang tidak memperlihatkan peranan PWD dalam membangunkan kemudahan tersebut.

Seterusnya hasil laporan yang disediakan oleh Mr Frederick Bolton berhubung dengan bekalan elektrik telah membawa kepada penubuhan Electrical Board pada April 1921. Walau bagaimanapun Electrical Board masih lagi sebuah jabatan di bawah PWD. Namun menariknya mengenai Electrical Board ialah peranannya yang semakin luas dengan melibatkan beberapa buah bandar utama iaitu Seremban dan Ipoh. Di Seremban, stesen yang sebelum ini dikendalikan oleh Syarikat United Engineers Limited telah diambil alih oleh Electrical Board mulai 1 Januari 1924. ${ }^{2}$ Manakala di Ipoh pula, bekalan elektrik pada mulanya diperolehi dari pengusaha lombong iaitu Pengkalen Tin Mines setidak-tidaknya sehingga tahun 1926 sebelum Electrical Board membina sebuah stesen janaelektrik yang baharu. ${ }^{3}$ Selain itu Electrical Board turut menyediakan kemudahan di beberapa kawasan lain seperti Klang, Taiping, Batu Gajah, Tanjong Malim, Kuala Kangsar dan Gemas. Melihat kepada peranan Electrical Board ini, jelas menunjukkan perkhidmatan yang disediakan lebih meluas dan meliputi sebahagian besar NNMB. Berikut merupakan stesen janaelektrik yang dikendalikan oleh Electrical Board sehingga tahun 1926:

\section{Jadual 1: Stesen Janaelektrik di bawah kendalian Electrical Board}

\begin{tabular}{|l|l|}
\hline Bandar/Pekan & Jumlah $(\mathbf{K} . \mathbf{W})$ \\
\hline Kuala Lumpur & 2,700 \\
\hline Kuala Lumpur (dalam pembinaan) & 9,000 \\
\hline Klang Estana & 3 \\
\hline Ipoh & 800 \\
\hline Kuala Kangsar & 10 \\
\hline Taiping Hospital & 30 \\
\hline Taiping Residency & 3 \\
\hline
\end{tabular}




\begin{tabular}{|l|l|}
\hline Batu Gajah Hospital & 24 \\
\hline Seremban & 580 \\
\hline Kuala Lipis & 3 \\
\hline Tanjong Malim & 14 \\
\hline Changkat Jong & 2.5 \\
\hline Bagan Serai Rice Mills & 5.5 \\
\hline Stesen Janaelektrik (Kereta Api) & \\
\hline Woodlands & 8.5 \\
\hline Gemas & 75 \\
\hline Tampin & 5 \\
\hline Port Dickson & 0.75 \\
\hline Kajang & 0.75 \\
\hline Sungai Besi & 0.75 \\
\hline Port Swettenham & 20 \\
\hline Central Workshops & 200 \\
\hline Rawang & 0.75 \\
\hline Tapah Road & 3 \\
\hline Ipoh & 50 \\
\hline Prai & 6 \\
\hline
\end{tabular}

Sumber: C.O. 717/53/17997, Creation of Separate Electrical Department and Appoint of Independent Head, hlm. 11.

Pada September 1926, C.V. Espeut yang merupakan Pengarah PWD dan Pengerusi Electrical Board menyatakan perlunya sebuah organisasi khas bagi menguruskan pembekalan elektrik yang tidak lagi tertakluk di bawah PWD. Menurut beliau adalah tidak wajar PWD yang merupakan antara jabatan terbesar di NNMB dibebani dengan hal-hal pengurusan bekalan elektrik yang semakin berkembang pesat. ${ }^{4}$ Selain itu, untuk memastikan pengurusan bekalan elektrik dapat dilaksanakan dengan lebih cekap ia seharusnya diketuai oleh seseorang yang berpengetahuan dalam bidang tersebut. ${ }^{5}$

Berikutan dengan itu, pada 1 Januari 1927 pihak kerajaan telah menubuhkan Jabatan Elektrik NNMB. ${ }^{6}$ Penubuhan Jabatan Elektrik dilihat menjadi perintis kepada perkembangan kemudahan bekalan elektrik kerana ia merupakan organisasi khusus yang ditubuhkan untuk membangunkan kemudahan tersebut di seluruh NNMB. Selain itu, Jabatan Elektrik juga dianggotai oleh mereka yang mempunyai kelayakan dan benar-benar mahir dalam hal-hal kejuruteraan elektrik. Misalnya W.J. Williams yang dilantik sebagai Pengarah mempunyai kelulusan dalam bidang kejuruteraan dari University of Liverpool dan pernah berkhidmat sebagai Penolong Jurutera di Supply Department of the Town Corporation of Leeds, England dan Pentadbir Tenaga Elektrik di Shanghai, China. Selain itu, beliau juga pernah ditugaskan untuk menguruskan pembinaan stesen janaelektrik di Hong Kong sebelum dilantik sebagai Ketua Jurutera di Penang Municipal Electric Supply Department untuk menguruskan pembinaan Stesen Janaelektrik Perai. ${ }^{7}$ Sementara D.M.W. Hutchison yang menyandang jawatan Ketua Jurutera pula berpengalaman luas dalam pembekalan elektrik di Tanah Melayu sebagai Chief Inspector of Electricity di NNMB dan Chief Electrical Engineer and Inspector masing-masing pada tahun 1915 dan $1926 .{ }^{8}$ Berikut merupakan senarai kakitangan Jabatan Elektrik NNMB: 
Pengarah - W.J. Williams

Ketua Jurutera Elektrik \& Inspektor - D.M.W. Hutchison

Timbalan Ketua Jurutera Elektrik - J.E. Catt

Eksekutif Jurutera Elektrik - E.A. Corbin

Penolong Jurutera Elektrik:

H.R. Sparrow (Pemangku Jurutera Elektrik, Kuala Lumpur)

E.F. Stephenson (Inspektor Elektrik, Perak)

C. Harry (Pemangku Jurutera Elektrik, Taiping)

L. Arnold (Jurutera utama, Kuala Lumpur)

F.P. Egerton (Jurutera Pembinaan, Klang)

T.E.R. Morphy (dipinjamkan ke Kelantan)

R.W. Jones (Pemangku Jurutera Elektrik, Seremban)

J. Hodder (Pemangku Jurutera Elektrik, Ipoh)

P.A. Bray (Penolong Penguasa Stesen, Kuala Lumpur)

R.H. Jones (Jurutera Talian Penghantaran, Kuala Lumpur)

H.H. Ewens (Pemangku Jurutera Elektrik, Klang)

L.G.W. Ward (bertugas di Ibu Pejabat)

G.S. Chapman (Jurutera, Kuala Lumpur)

F.J. Larard (Jurutera Pembinaan, Bentong)

Setiausaha - A.W. Every

Akauntan - E.S. Statham

Foreman - N.C.J. Saunders \& B.F. Lewin

Shift Engineers :

G. Harris, Stesen Kuala Lumpur

W. Berry, Stesen Kuala Lumpur

A.T. Boteler, Stesen Kuala Lumpur (sementara)

G.E. Vickers, Stesen Kuala Lumpur (sementara)

W.H. Lake, Stesen Kuala Lumpur (sementara)

Melihat kepada struktur organisasi Jabatan Elektrik khususnya bagi jawatan Penolong Jurutera Elektrik, didapati ada beberapa kakitangan ditempatkan di Ipoh, Taiping, Klang, Seremban dan Bentong. Secara tersiratnya, penempatan pegawai tersebut menunjukkan usaha membangunkan bekalan elektrik mula melibatkan seluruh NNMB. Justeru, usaha kerajaan dengan menubuhkan organisasi yang khusus merupakan sesuatu yang sangat penting dalam mengkoordinasikan pembangunan bekalan elektrik di negeri-negeri berkenaan.

Serentak dengan kewujudan organisasi ini, usaha telah diambil dengan membina stesen janaelektrik dan menguruskan sistem pembekalannya. Pembinaan stesen janaelektrik penting kerana ia merupakan satu-satunya cara untuk menjana tenaga elektrik. Manakala sistem pembekalannya pula merupakan cara untuk membekalkan tenaga elektrik kepada pengguna mengikut keperluan sama ada untuk sektor ekonomi mahupun domestik. Langkah ini merupakan sesuatu yang penting dan menjadi kunci utama kepada perkembangan kemudahan bekalan elektrik di NNMB.

Pada 6 Oktober 1893, Alfred Venning telah mengemukakan cadangan untuk menyediakan bekalan elektrik di Kuala Lumpur. Rentetan daripada ini dua skim telah dikemukakan masing-masing oleh Spooner dan L.C. Bell. Spooner telah mencadangkan supaya bekalan elektrik dijana dengan menggunakan kaedah hidro sama ada melalui Sungai Gombak atau Sungai Klang. Sementara L.C. Bell pula mencadangkan sebuah stesen janaelektrik jenis stim dibina di Kuala Lumpur. Setelah mengajukan kedua-dua skim tersebut kepada pakar di London iaitu Syarikat Preece \& Cardew, pihak kerajaan mengambil 
keputusan untuk menggunakan skim yang dicadangkan oleh Sponner dengan membina stesen hidro di Sungai Gombak. ${ }^{9}$

Pada tahun 1905, kerja-kerja pembinaan Stesen Hidroelektrik Hulu Gombak yang dilengkapi dua set turbin dengan kapasiti $400 \mathrm{KW}$ telah siap dan memulakan operasinya membekalkan elektrik untuk kegunaan Kuala Lumpur. ${ }^{10}$ Sehingga penghujung tahun 1906, sebanyak enam bangunan kerajaan, 102 buah rumah dan beberapa lampu jalan di Kuala Lumpur mendapat kemudahan bekalan elektrik. ${ }^{11}$ Tidak lama selepas itu, sebuah stesen janaelektrik telah dibina di Lorong Gombak untuk meningkatkan lagi bekalan elektrik bagi menampung permintaan di Kuala Lumpur. Selaras dengan pembinaan stesen janaelektrik tersebut, pihak PWD telah menyediakan peruntukan khas untuk kerja-kerja penyambungan dan penambahbaikan pembekalan elektrik. Pada tahun 1912, PWD membelanjakan kira-kira $\$ 86,000$ untuk tujuan tersebut dan $\$ 90,025$ untuk kerja-kerja penyelenggaraan. ${ }^{12}$ Perkhidmatan bekalan elektrik yang disediakan di Kuala Lumpur dilihat menunjukkan permintaan yang menggalakkan. Hal ini dapat dinilai menerusi pertambahan unit bekalan elektrik yang dijual kepada pengguna. Pada tahun 1915, jumlah unit bekalan elektrik yang dijual sekitar 181,000 unit. Jumlah tersebut menunjukkan peningkatan kepada 1,495,000 unit pada tahun 1916; 1,708,832 unit pada tahun 1917 dan 2,233,988 unit pada tahun $1918 .{ }^{13}$

Menerusi Electrical Board pula, tumpuan diberikan kepada penyelenggaraan stesen yang dibina oleh PWD sebelum ini. Selain itu tumpuan diberikan kepada kerja-kerja menaik taraf sub-stesen yang sedia ada untuk meningkatkan lagi kapasiti penjanaan. Pada tahun 1922, Electrical Board telah menyiapkan pemasangan transformer di Sub-Stesen Pudu bagi meningkatkan kapasiti penjanaan dari 75 KVA kepada 150 KVA. Manakala di Sub-Stesen Ampang pula dua set transformer 75 KVA telah siap dipasang sementara di Sub-Stesen Sentul dua set transformer $50 \mathrm{KVA}$ dipasang untuk meningkatkan kapasiti penjanaan dari 550 KVA kepada 1,000 KVA. ${ }^{14}$ Terdapat juga sub-stesen baharu yang dibina oleh Electrical Board seperti di Kia Peng Road, Penang Road dan Bangsar Road.

Bagi meluaskan kawasan pembekalannya, penyambungan sesalur atas (overhead mains) telah dilakukan di Circular Road, New General Hospital, Penang Road, Kia Peng Road, Temple Road dan Chan Ah Tong Street.Manakala sesalur bawah tanah (underground mains) telah dihubungkan di Ywe Swi Guat Street dan Rodger Street. ${ }^{15}$ Selain itu Electrical Board turut melakukan kerja-kerja penyelenggaraan stesen di Klang yang melibatkan kos sebanyak $\$ 3,041.58$.

Di Perak pula, kawasan yang menjadi tumpuan Electrical Board ialah Ipoh, Taiping, Kampar, Batu Gajah, Kuala Kangsar dan Tanjong Malim. Bagi kawasan Ipoh, pihak Electrical Board hanya menguruskan pembekalannya sahaja kerana tenaga elektrik diperolehi dari stesen kepunyaan Pengkalen Tin Mines. ${ }^{16}$ Untuk itu Electrical Board telah membina dua buah sub-stesen di Hugh Low Road dan Cowan Road seterusnya dihubungkan ke Pengkalen dengan Lahat Lane. ${ }^{17}$ Dari Lahat Lane, kabel bawah tanah dihubungkan ke Sub-Stesen Hugh Low dan seterusnya ke Sub-stesen Cowan yang masing-masing dilengkapi dengan dua set transformer $200 \mathrm{KVA}$ untuk mengurangkan voltan sebelum dibekalkan kepada pengguna. ${ }^{18}$ Sama seperti di Ipoh, bekalan elektrik di Kampar juga diperolehi dari pengusaha lombong iaitu Societe Francaise des Mines d'Etains de Kinta. ${ }^{19}$ Bagi kawasan Taiping dan Batu Gajah pula, pihak Electrical Board menyediakan bekalan elektrik hanya untuk kegunaan hospital sahaja. Manakala di Tanjong Malim pula, sebuah stesen yang dilengkapi set enjin jenis Tangye 30 H.P. dan E.C.C. $15 \mathrm{KW}$ telah dibina untuk membekalkan elektrik bagi kegunaan Sultan Idris Training Collage. ${ }^{20}$

Sementara di Negeri Sembilan pula, Electrical Board telah melanjutkan tempoh konsesi Syarikat United Engineers Limited yang sepatutnya tamat pada 31 Julai 1923 kepada 31 Disember 1923. Berikutnya, pada 1 Januari 1924 tugas tersebut telah diambil alih oleh Electrical Board. Serentak dengan itu, usaha untuk meluaskan kawasan pembekalan telah 
dilakukan melibatkan kawasan Carew, Wilkinson, Cameron, Lemon Street, Temiang, Egerton, Rahang, Dunman Road, Jalan Tuan Sheik dan Jalan Tungku Hassan. ${ }^{21}$ Di samping itu, Jurutera Elektrik di Seremban turut membantu menyelaraskan pembekalan elektrik untuk kegunaan 12 lampu jalan di Gemas yang mendapat bekalan elektrik dari stesen janaelektrik kereta api. ${ }^{22}$

Jadual 2: Jumlah unit tenaga elektrik yang dijana dan dijual, 1922-1926

\begin{tabular}{|l|l|l|l|l|l|l|}
\hline \multirow{2}{*}{ Tahun } & \multicolumn{2}{|l|}{ Kuala Lumpur } & Ipoh & Seremban & \\
\cline { 2 - 7 } & $\begin{array}{l}\text { Unit } \\
\text { Dijana }\end{array}$ & $\begin{array}{l}\text { Unit } \\
\text { Dijual }\end{array}$ & $\begin{array}{l}\text { Unit } \\
\text { Dibeli }\end{array}$ & $\begin{array}{l}\text { Unit } \\
\text { Dijual }\end{array}$ & $\begin{array}{l}\text { Unit } \\
\text { Dijana }\end{array}$ & $\begin{array}{l}\text { Unit } \\
\text { Dijual }\end{array}$ \\
\hline 1922 & $2,324,800$ & $1,832,051$ & - & - & - & - \\
\hline 1923 & $2,862,929$ & $2,238,878$ & 284,218 & 174,103 & - & - \\
\hline 1924 & $3,256,973$ & $2,495,820$ & 840,870 & 671,235 & 452,435 & 352,400 \\
\hline 1925 & $3,585,477$ & $2,669,973$ & 983,181 & 831,699 & 498,458 & 465,589 \\
\hline 1926 & $4,010,351$ & $3,205,595$ & $1,550,732$ & $1,434,629$ & 750,425 & 639,177 \\
\hline
\end{tabular}

Sumber: Annual Report of the Electrical Board, 1922-1926.

Jadual 3: Bilangan pengguna yang mendapat kemudahan bekalan elektrik yang disediakan oleh Electrical Board

\begin{tabular}{|l|l|l|l|l|l|l|}
\hline \multirow{2}{*}{ Tahun } & \multicolumn{2}{|c|}{ Kuala Lumpur } & \multicolumn{2}{c|}{ Ipoh } & \multicolumn{2}{c|}{ Seremban } \\
\cline { 2 - 7 } & Kerajaan & Persendirian & Kerajaan & Persendirian & Kerajaan & Persendirian \\
\hline 1922 & 359 & 1,201 & - & - & - & - \\
\hline 1923 & 383 & 1,585 & 80 & 836 & - & - \\
\hline 1924 & 388 & 1,661 & 90 & 1,101 & 223 & 338 \\
\hline 1925 & 403 & 1,766 & 100 & 1,136 & 310 & 458 \\
\hline 1926 & 414 & 1,807 & 116 & 1,306 & 343 & 544 \\
\hline
\end{tabular}

Sumber: Annual Report of the Electrical Board, 1922-1926.

Berdasarkan kepada kerja-kerja pembinaan stesen janaelektrik dan pengurusan sistem pembekalan yang dilakukan oleh Electrical Board, jelas menunjukkan kejayaannya dalam membangunkan kemudahan bekalan elektrik. Walaupun perkhidmatan yang disediakan tidak melibatkan keseluruhan NNMB, namun setidak-tidaknya pihak Electrical Board berjaya menyediakan kemudahan tersebut di beberapa kawasan di Selangor, Perak dan Negeri Sembilan.Walau bagaimanapun, ini tidak bermakna pihak kerajaan meminggirkan Pahang. Sebaliknya usaha telah diambil dengan merangka skim pembekalan elektrik untuk beberapa kawasan di Pahang seperti Raub, Bentong, Kuala Lipis dan Kuantan. Penyediaan kemudahan bekalan elektrik bagi kawasan tersebut dikendalikan pula oleh Electrical Department yang ditubuhkan bagi menggantikan Electrical Board.

Usaha kerajaan menubuhkan Electrical Department telah merancakkan lagi pembangunan kemudahan bekalan elektrik di NNMB. Di Selangor, Kuala Lumpur masih lagi menjadi tumpuan utama dalam penyediaan bekalan elektrik. Electrical Department bertanggungjawab mengendali Stesen Janaelektrik Bangsar yang telah dibina sejak tahun 1926 lagi. Stesen yang dibina dengan kapasiti 9,000 KW itu telah ditingkatkan kapasitinya dengan menambah sebuah set penjanaan berkapasiti 10,000 KW untuk menampung permintaan yang semakin meningkat. Manakala Stesen Hidro-Elektrik Hulu Gombak dan sebuah stesen janaelektrik jenis diesel di Kuala Lumpur telah diberhentikan operasinya pada penghujung bulan Julai 1927. Beberapa peralatan set diesel dari stesen janaelektrik Kuala Lumpur telah digunakan untuk pembinaan stesen janaelektrik di Klang. Electrical 
Department kemudiannya telah membeli Stesen Hidro Elektrik Ulu Langat dari Sungai Besi Mines pada 1 April 1933. ${ }^{23}$

Electrical Department juga bertanggungjawab mengendalikan perkhidmatan bekalan elektrik bagi kawasan yang sebelum ini di bawah tanggungjawab Electrical Board. Selain itu beberapa kawasan yang sebelum ini tidak mendapat kemudahan bekalan elektrik mula diberi perhatian oleh Electrical Department.Antara kawasan tersebut ialah Gemas dan Port Dickson di Negeri Sembilan dan Port Swetenham di Selangor. Di Gemas, stesen janaelektrik jenis stim milik FMS Railway yang dikendalikan oleh Electrical Department telah digantikan dengan sebuah stesen janaelektrik yang baru. ${ }^{24}$ Manakala di Port Dickson pula sebuah bangunan stesen janaelektrik mula dibina pada 3 September 1931 selain talian penghantaran yang menghubungkan Port Dickson dengan Bagan Pinang. ${ }^{25}$

Sebagaimana yang dinyatakan, Electrical Department memainkan peranan dalam menyediakan bekalan elektrik di Pahang yang sebelum ini tidak dilakukan oleh Electrical Board mahupun PWD. Pada lewat tahun 1920, usaha telah diambil untuk membekalkan elektrik di Raub, Bentong dan Kuala Lipis.Bekalan elektrik untuk kegunaan kawasan Raub diperolehi dari stesen milik Raub Australian Gold Mining Limited manakala untuk kawasan Bentong pula diperolehi dari Tin Bentong Limited. ${ }^{26}$ Pada 21 November 1928, kerja-kerja membina sub-stesen dan tiang elektrik di Bentong telah dijalankan dan siap sepenuhnya pada 9 Mac 1929. Pada mulanya bekalan elektrik disediakan dari 6 petang sehingga 6 pagi sebelum dilanjutkan untuk tempoh 24 jam mulai 16 April 1929. ${ }^{27}$ Bagi kawasan Kuala Lipis pula, sebuah stesen janaelektrik yang beroperasi menggunakan minyak telah dibina bermula Mei $1929 .^{28}$ Memasuki tahun 1931, sebuah stesen janaelektrik yang dilengkapi dua enjin diesel berkapasiti $100 \mathrm{KW}$ telah dibina di Kuantan. ${ }^{29}$ Pada mulanya tenaga elektrik dibekalkan untuk tempoh 12 jam sebelum dilanjutkan kepada 24 jam mulai 19 Mei 1932. ${ }^{30}$ Seterusnya pada tahun 1939, sebuah stesen janaelektrik yang dilengkapi dua enjin diesel telah siap dibina di Mentakab dan dihubungkan ke Temerloh. Seramai 145 pengguna di Mentakab dan 111 lagi di Temerloh mendapat kemudahan bekalan elektrik menerusi stesen penjanaan tersebut. ${ }^{31}$ Pada masa yang sama sebuah stesen janaelektrik dengan dua set enjin telah siap dibina di Fraser's Hill untuk kegunaan lampu jalan dan awam. ${ }^{32}$ Walaupun bermula agak lewat jika dibandingkan dengan NNMB yang lain, didapati pihak Electrical Department telah berjaya menyediakan kemudahan bekalan elektrik di Pahang. Hal ini dapat dilihat menerusi bilangan pengguna yang semakin bertambah.

Jadual 4: Bilangan pengguna yang mendapat kemudahan bekalan elektrik di Pahang

\begin{tabular}{|l|l|l|l|l|}
\hline Tahun & Raub & Kuala Lipis & Kuantan & Bentong \\
\hline 1929 & 149 & 182 & - & 270 \\
\hline 1930 & 210 & 220 & - & 289 \\
\hline 1931 & 234 & 248 & 255 & 273 \\
\hline 1932 & 250 & 260 & 284 & 270 \\
\hline 1933 & 256 & 301 & 288 & 267 \\
\hline 1934 & 261 & 345 & 309 & 291 \\
\hline 1935 & 259 & 362 & 344 & 309 \\
\hline 1936 & 267 & 379 & 359 & 306 \\
\hline 1937 & 274 & 399 & 390 & 331 \\
\hline 1938 & 317 & 431 & 415 & 369 \\
\hline
\end{tabular}

Sumber: Annual Report and Accounts of the Electrical Department, 1929-1938. 
Selain menguruskan pembinaan stesen janaelektrik,Electrical Department turut memainkan peranan membekalkan tenaga elektrik untuk kegunaan ekonomi khususnya sektor perlombongan bijih timah.Walaupun dalam konteks NNMB, Perak dan Selangor berkembang pesat dengan sektor perlombongan bijih timah, namun perkhidmatan yang disediakan oleh Jabatan Elektrik hanya tertumpu di Selangor. Sementara di Perak pula ia dikendalikan oleh syarikat swasta. Pada awal penubuhannya, Electrical Department telah berjaya membekalkan elektrik kepada beberapa lombong bijih timah seperti Batu Caves Tin Dredging Ltd., Ulu Klang Tin Dredging Co Ltd., Puchong Tin Dredging Co Ltd. dan Sungai Way Tin Dredging Co Ltd. ${ }^{33}$

Bagi memastikan tenaga elektrik dapat dibekalkan ke lebih banyak kawasan perlombongan, Electrical Department telah meluaskan lagi rangkaian penghantaran mereka. Misalnya talian penghantaran bekalan elektrik dihubungkan dari Sungai Besi ke Serdang untuk membekalkan elektrik ke Lombong Tet Lee, Lombong Weng Loong dan Lombong Hock Hin. ${ }^{34}$ Pada masa yang sama Jabatan Elektrik turut membina sub-stesen baru untuk kegunaan melombong seperti di Lombong Toong Loy di Sungai Way dan Lombong Hong Fatt di Serdang. ${ }^{35}$ Perkhidmatan yang disediakan oleh Electrical Department dilihat banyak membantu pengusaha lombong bijih timah menjalankan kerja-kerja melombong dan seterusnya meningkatkan lagi hasil pengeluaran. Antara lombong yang mendapat kemudahan tersebut ialah Ying Tong, Ampang; Cheong Hin, Serdang; Tuck Khong, Pudu; Low Ti Kok, Cheras; Soon Aik, Sungai Besi; Weng Fatt, Jalan Cheras; Yap Swee Yoon, Serdang; Wong Choy, Sungai Way; Tai Yau Mine, Salak South; Swee Hin, Kepong; Chim Lee, Kepong; Loong Hin, Setapak; Yew Fong Kongsi, Ampang; Yee Tak Fatt, Sungai Besi; Tong Sang, Serdang; Ban Ho, Kepong dan Tung Soon, Pudu Ulu. ${ }^{36}$ Selain sektor perlombongan, Electrical Department turut membekalkan bekalan elektrik untuk kegunaan Federated Malay States Rubber Factory, Kajang; Puchong Estate Rubber Factory; Federated Malay States Railways; Ulu Buloh Leprosorium; lampu jalan dan sebagainya. Diperhatikan, bilangan pengguna yang mendapat kemudahan bekalan elektrik menerusi pihak Electrical Department terus menunjukkan peningkatan.

Jadual 5: Bilangan pengguna yang mendapat kemudahan bekalan elektrik yang disediakan oleh Electrical Department

\begin{tabular}{|l|l|l|l|}
\hline Tahun & Kuala Lumpur & Ipoh & Seremban \\
\hline 1927 & 3,097 & 1,698 & 1,041 \\
\hline 1928 & 4,109 & 2,098 & 1,165 \\
\hline 1929 & 4,967 & 2,737 & 1,353 \\
\hline 1930 & 6,091 & 3,302 & 1,527 \\
\hline 1931 & 6,906 & 3,478 & 1,609 \\
\hline 1932 & 6,886 & 3,551 & 1,690 \\
\hline 1933 & 6,529 & 3,631 & 1,700 \\
\hline 1934 & 6,945 & 3,844 & 1,758 \\
\hline 1935 & 7,184 & 4,114 & 1,784 \\
\hline 1936 & 7,735 & 4,293 & 1,820 \\
\hline 1937 & 9,356 & 4,527 & 1,887 \\
\hline 1938 & 10,055 & 4,750 & 1,974 \\
\hline
\end{tabular}

Sumber: Annual Report and Accounts of the Electrical Department, 1927-1938.

Sesuatu yang menarik mengenai perkhidmatan yang disediakan oleh Electrical Department ialah pembekalan elektrik untuk kegunaan kawasan pekan dan luar bandar. Keadaan ini menunjukkan Electrical Department tidak hanya menfokuskan kawasan tertentu sahaja seperti kawasan bandar atau yang berpotensi dari segi ekonomi dalam perkhidmatan 
mereka.Sehingga tahun 1939, terdapat sekurang-kurangnya 12 buah pekan dan kampung mendapat kemudahan bekalan elektrik. Kawasan tersebut ialah Sungai Besi, Kajang, Serdang, Puchong, Kepong, Ampang, Salak South, Ulu Kelang, Sungai Buloh, Pudu Ulu, Sungai Way dan Petaling.

Jadual 6: Bilangan kawasan luar bandar yang mendapat kemudahan bekalan elektrik

\begin{tabular}{|c|c|c|c|c|c|c|c|c|}
\hline $\begin{array}{l}\text { Tahun } \\
\text { Pekan/ } \\
\text { Kampung }\end{array}$ & 1932 & 1933 & 1934 & 1935 & 1936 & 1937 & 1938 & 1939 \\
\hline Kajang & 237 & 252 & 299 & 319 & 335 & 352 & 439 & 470 \\
\hline Serdang & 160 & 150 & 158 & 167 & 174 & 179 & 178 & 190 \\
\hline Puchong & 18 & 22 & 24 & 25 & 25 & 28 & 29 & 29 \\
\hline Kepong & 82 & 77 & 80 & 81 & 80 & 84 & 94 & 106 \\
\hline Ampang & 72 & 62 & 67 & 77 & 84 & 99 & 106 & 116 \\
\hline Salak & 56 & 55 & 62 & 88 & 73 & 85 & 86 & 106 \\
\hline Sungai Buloh & 31 & 25 & 25 & 28 & 28 & 28 & 29 & 33 \\
\hline Ulu Klang & 17 & 18 & 20 & 23 & 26 & 28 & 32 & 33 \\
\hline Pudu Ulu & 35 & 33 & 43 & 49 & 48 & 47 & 57 & 65 \\
\hline Sungai Besi & - & - & 40 & 46 & 57 & 65 & 74 & 101 \\
\hline Sungai Way & - & - & - & - & - & - & 24 & 27 \\
\hline Petaling & - & - & - & - & - & - & - & 24 \\
\hline
\end{tabular}

Sumber: Annual Report and Accounts of the Electrical Department, 1932-1939.

Selain itu, dalam usaha untuk membangunkan kemudahan bekalan elektrik, pihak kerajaan memainkan peranan dengan memberi penekanan terhadap aspek perundangan. Tumpuan terhadap pembangunan fizikal semata-mata dilihat tidak dapat menjamin kesempurnaannya. Sebaliknya, ia perlu disertakan dengan aspek tambahan lain seperti undang-undang. Kaedah ini penting dalam mengkoordinasikan perkhidmatan yang disediakan sama ada oleh pihak kerajaan mahupun swasta serta menitik beratkan para pengguna.Sehubungan dengan itu, kerajaan telah menguatkuasakan enakmen No. 23 Tahun 1913, The Electricity Enactment, 1913 pada 1 Mac 1914. Perlaksanaan enakmen tersebut bertujuan "...to provide for the regulation and control of Electricity Installations and of the generation, supply, and use of Electrical Energy". 37

Antara perkara yang dinyatakan di dalam enakmen tersebut ialah perlantikan Electrical Inspector. Menurut Fasal 3, Chief Secretary boleh melantik seberapa ramai Electrical Inspector untuk menjalankan tugas pemeriksaan ke atas pemasangan, stesen janaelektrik, peralatan dan kerja-kerja pembinaan. ${ }^{38}$ Langkah ini sangat penting bagi memastikan bilangan kakitangan sentiasa mencukupi untuk melakukan tanggungjawab tersebut. Tambahan pula kepentingan bekalan elektrik membuatkan banyak stesen janaelektrik telah dibina.Bersesuaian dengan Fasal 3, terdapat sekurang-kurangnya dua lagi fasal yang saling berkaitan iaitu Fasal 12 dan 13. Merujuk kepada Fasal 12, setiap stesen janaelektrik yang telah siap dibina perlu dimaklumkan kepada Chief Inspector yang akan melakukan pemeriksaan bagi memastikan kesempurnaannya. ${ }^{39}$ Manakala Fasal 13 pula menyatakan mengenai tempoh pemeriksaan terhadap stesen janaelektrik iaitu semasa pembinaan dan setelah siap dibina. Selain itu pemeriksaan juga akan dilakukan ke atas pemasangan yang telah beroperasi sekurang-kurangnya sekali dalam tempoh enam bulan. ${ }^{40}$ Kesemua ini penting bagi memastikan stesen dapat beroperasi dengan sebaik mungkin dan mengelakkan timbulnya sebarang masalah kelak.

Tidak dinafikan terdapat pengusaha lombong bijih timah yang menghasilkan bekalan elektriknya sendiri.Justeru, untuk memastikan perkhidmatan bekalan elektrik diuruskan 
dengan betul, pihak kerajaan mengawalnya dengan pemberian lesen. Hal ini sebagaimana yang dinyatakan di dalam Fasal 4 yang memerlukan seseorang itu mendapatkan lesen terlebih dahulu sebelum mengendalikan stesen janaelektrik. ${ }^{41}$ Pemberian lesen ini juga penting bagi membolehkan kerajaan mengawal had voltan, penggunaan elektrik dan tempoh konsesi. Misalnya pada 29 April 1937 kerajaan telah memberi lesen kepada Lombong Ying Nam Tin untuk menguruskan pemasangan elektrik di Batu 6 1/2 Petaling, Jalan Kuchai, Salak South. Menerusi pemberian lesen tersebut, beberapa syarat dikenakan iaitu pengusaha hendaklah menjana elektrik dengan menggunakan set generator arus terus berkapasiti $15 \mathrm{KW}$; voltan yang dibenarkan untuk penjanaan dan pembekalan ialah $230 \mathrm{~V}$ dan tempoh sah lesen dari 1 April 1937 sehingga 1 April 1939. ${ }^{42}$ Manakala pada 28 Mei 1937, lesen telah diberikan kepada Ban Sin Kongsi untuk menguruskan pemasangan elektrik di Salak Petaling, Selangor. Syarat-syarat yang dikenakan ialah tenaga elektrik hendaklah dijana dengan set generator arus terus berkapasiti $6.5 \mathrm{KW}$; voltan yang dibenarkan untuk penjanaan dan pembekalan ialah $110 \mathrm{~V}$ dan tempoh sah lesen bermula 1 April 1937 sehingga 1 April 1939. ${ }^{43}$

Di samping itu, pihak kerajaan turut memainkan peranan dalam pembangunan sumber manusia.Dalam usaha membangunkan kemudahan bekalan elektrik, tumpuan tidak seharusnya terarah kepada aspek mekanikal sahaja sebaliknya perlu digabungkan dengan ilmu pengetahuan dan kemahiran. Lebih-lebih lagi kemudahan tersebut merupakan sesuatu yang baru dan memerlukan kemahiran khusus dalam mengendalikannya. Bagi melahirkan kakitangan yang mengendalikan perkhidmatan bekalan elektrik mempunyai kemahiran dan kelayakan, pihak kerajaan telah mengadakan peperiksaan khas. Peperiksaan ini pada mulanya diadakan di Kuala Lumpur dan Ipoh sebelum diperluaskan ke Seremban. Menerusi peperiksaan yang dijalankan, ia melahirkan beberapa kelas kakitangan seperti Electrical Engineer, Chargeman dan Wiremen. Pada tahun 1926, seramai tujuh orang Electrical Engineer, 27 orang Chargemen dan 23 orang Wiremen telah lulus ujian yang diadakan. ${ }^{44}$ Langkah ini selaras dengan Fasal 15, Enakmen Elektrik yang menyatakan bahawa:

"No installation or electrical plant or apparatus shall be worked or operated except by or under the control of person possessing such qualification and holding such certificates as may be prescribed, and no person not possessing such qualification or holding such certificates shall work or operated any installation or electrical plant or apparatus except under such control as aforesaid" 45

Pada masa yang sama pihak kerajaan turut menitik beratkan aspek pendidikan. Bagi maksud tersebut, mereka yang melanjutkan pengajian dalam bidang berkaitan di Maktab Teknik, Kuala Lumpur akan diambil sebagai perantis di Electrical Department. Langkah ini penting sebagai pendedahan awal sebelum mereka memulakan perkhidmatan. Antara mereka yang mendapat pendidikan di Maktab Teknik dan menjadi perantis ialah Walter Fitzpatrik, Edward Roger Weerasingham Lee, Chin Kim Choon, Markandoo, Maniam, O'Neil, Yzelman, Nathan, Raja Harun, Muthuthamby, Hamid, Yim Mun Toh, Keun, Subramaniam, Harnam Singh dan Muthiah. ${ }^{46}$ Tidak cukup dengan itu, pihak kerajaan juga turut memberi bantuan biasiswa kepada beberapa individu untuk melanjutkan pengajian di luar negara dalam bidang kejuruteraan elektrik. Individu pertama yang mendapat tawaran tersebut ialah Raja Tan Sri Zainal bin Raja Sulaiman yang melanjutkan pengajiannya di University Brimingham sekitar tahun 1930-an. ${ }^{47}$ Seterusnya diikuti oleh Tan Sri Dato' Abu Zarim bin Haji Omar dan Tengku Daud bin Tengku Besar Burhanuddin yang mendapat biasiswa dari Kerajaan Negeri Sembilan. Pada mulanya kedua-dua mereka diambil menjadi perantis di Electrical Department dan dijadualkan untuk melanjutkan pengajian di salah sebuah unversiti di Australian pada awal tahun 1940-an. Namun Perang Dunia Kedua yang meletus 
membuatkan hasrat mereka tertangguh dan hanya melanjutkan pengajian di United Kingdom sebaik sahaja perang tamat. ${ }^{48}$

\section{Syarikat Swasta}

Selain pihak kerajaan, perkembangan kemudahan bekalan elektrik di NNMB turut dibantu oleh perkhidmatan yang disediakan oleh syarikat swasta dan pengusaha lombong. Malah tidak dapat dinafikan bahawa syarikat perlombongan dilihat mendahului pihak kerajaan dalam membangunkan kemudahan bekalan elektrik. Walau bagaimanapun, fokus utama penyediaan bekalan elektrik pada ketika itu lebih terarah kepada kepentingan meraka iaitu untuk kerja-kerja melombong. Bagi memastikan bekalan elektrik untuk kegunaan melombong dapat disediakan, syarikat swasta mengambil inisiatif dengan membina stesen janaelektrik.

Syarikat Raub Australian Gold Mining Limited (RAGM) mencatat sejarah penting dalam perkhidmatan bekalan elektrik apabila membina stesen hidro elektrik pertama di Tanah Melayu. Konsesi Sungai Sempam yang diberikan kepada RAGM pada 6 April 1892 membolehkan pihak syarikat membina stesen hidro elektrik dan menggunakan arus sungai untuk menjana tenaga elektrik. ${ }^{49}$ Air Sungai Sempam dialirkan melalui paip keluli ke stesen yang dilengkapi tiga enjin untuk menghasilkan tenaga elektrik sehingga 5,000 V sebelum ditingkatkan kepada $10,000 .^{50}$ Tenaga elektrik yang terhasil digunakan untuk mesin gerudi, jentera pam, motor elektrik, mesin pelebur bijih dan penghancur emas.Selain untuk kerjakerja melombong emas, bekalan elektrik yang dijana turut dibekalkan ke rumah pekerja dan kilang. Walaupun RAGM menjadi syarikat pertama membina stesen janaelektrik jenis hidro, namun tenaga yang dihasilkan hanya untuk kegunaan persendirian pihak syarikat.

Sebuah lagi syarikat swasta yang memainkan peranan penting dalam membangunkan kemudahan bekalan elektrik di NNMB khususnya Perak ialah Perak River-Hydro Electric Company (PRHEP). Berbanding dengan RAGM, peranan yang dimainkan oleh PRHEP dilihat lebih menonjol walaupun tenaga elektrik yang dihasilkan digunakan untuk sektor perlombongan. Hal ini kerana PRHEP membekalkan tenaga elektrik untuk kegunaan pelombong bijih timah di beberapa kawasan di Perak.

Pada Disember 1925, satu perjanjian telah ditandatangani antara Sultan Perak, Sultan Iskandar Syah dengan Sir W. G. Armstrong Whitworth \& Company berhubung cadangan membekalkan elektrik di Perak. Hasilnya pada 28 Julai 1926 PRHEP telah ditubuhkan. ${ }^{51}$ Merujuk kepada fasal 18 perjanjian, Syarikat PRHEP diberi tempoh konsesi membekalkan elektrik di Perak selama 80 tahun. Namun pihak kerajaan berhak untuk menamatkan konsesi selepas tempoh 50 tahun perkhidmatan. ${ }^{52}$ Perjanjian yang mengandungi 43 fasal itu antara lain menyatakan dengan jelas berkenaan pemasangan alat penjanaan; kadar bayaran yang dikenakan kepada pengguna; tindakan terhadap syarikat sekiranya berlaku kegagalan dalam membekalkan elektrik; pembekalan elektrik dan sebagainya. Selain itu pihak syarikat turut diberi kebenaran untuk menggunakan Sungai Perak sama ada melakukan kerja-kerja mendalamkan sungai, membina tebing, mengalirkan arus sungai dan sebagainya dengan tujuan menjana tenaga elektrik.

Peranan PRHEP dalam membangunkan kemudahan bekalan elektrik dapat dilihat menerusi pembinaan stesen janaelektrik. Pada April 1928 kerja-kerja membina Stesen Hidro Elektrik Chenderoh telah dijalankan yang melibatkan beberapa kontraktor seperti Topham, Jones \& Railton Ltd.; Glenfield \& Kennedy Ltd.; Ramsomes \& Rapier Ltd.; The English Steel Corporation Ltd dan The English Electric Co. Ltd. ${ }^{53}$ Stesen Hidro Elektrik Chenderoh yang memulakan operasinya secara rasmi pada 28 Jun 1930 mampu menghasilkan tenaga elektrik sehingga $27,000 \mathrm{KW} .^{54}$ Selain itu PRHEP turut membina sebuah stesen janaelektrik jenis stim di Malim Mawar yang beroperasi menggunakan arang batu. Kerja-kerja pembinaan dimulakan pada Oktober 1927 yang melibatkan syarikat kontraktor International Combustion 
Ltd.; The English Electric Co. Ltd.; James Howden \& Co. Ltd.; W.T. Glover \& Co. Ltd.; Ledward \& Beckett Ltd. dan S. Bullock \& Co. Ltd. ${ }^{55}$ Stesen Malim Mawar siap dibina dan mula beroperasi pada November 1928. Pada mulanya, kapasiti penjanaan stesen tersebut ditetapkan pada $5,000 \mathrm{~kW}$. Namun semasa proses pembinaan sedang dijalankan keputusan telah diambil untuk meningkatkan kapasiti penjanaan sehingga $12,000 \mathrm{~kW}$ sebelum ditingkatkan kepada $18,000 \mathrm{~kW}$ dengan menambah peralatan jenis turbo-alternator berkuasa $6,000 \mathrm{KW} .{ }^{56}$ Stesen Malim Mawar dibina untuk membekalkan elektrik kepada pengguna di Kinta sementara menunggu Stesen Chenderoh siap sepenuhnya dan sebagai bekalan tambahan sekiranya berlaku kerosakan atau musim kemarau yang menyukarkan Stesen Chenderoh untuk menjana tenaga elektrik mengikut keperluan. Setelah siap dibina, talian penghantaran $66 \mathrm{kV}$ telah dihubungkan antara kedua-dua stesen tersebut.

Peranan PRHEP dalam membina stesen janaelektrik telah memberi banyak manfaat kepada pengusaha lombong bijih timah. Terdapat beberapa pengusaha lombong telah menandatangani perjanjian dengan PRHEP untuk mendapatkan bekalan elektrik.

Jadual 7: Lombong bijih timah yang mendapat bekalan elektrik dari PRHEP

\begin{tabular}{|l|l|l|}
\hline Nama Lombong & Kawasan & $\begin{array}{l}\text { Permintaan } \\
\text { Bekalan }\end{array}$ \\
\hline Alluvial Tin (Malaya Ltd.) & Kramat & 350 K.W. \\
\hline Societe des Etains de Kinta & Kampar & 1,350 K.V.A. \\
\hline Kinta Tin Dredging & Batu Gajah & 400 K.W. \\
\hline Chan Tat Cho & Kampar \& Chenderiang & 275 K.V.A. \\
\hline Wong Peng Sam & Kampar & 250 K.W. \\
\hline Choo Hoy & Temoh \& Chenderiang & 2,000 K.W. \\
\hline Wong Seong & Kampar & 60 K.W. \\
\hline Loke ManChoke & Kampar & 300 K.V.A \\
\hline Tujoh Tin & Temoh & 400 K.W. \\
\hline C.E. Cumming & Papan & 1,000 K.W. \\
\hline Penawat (Malaya) Tin Dredging & Tanjong Toh Alang & 600 K.W. \\
\hline Kampar Malaya Tin Dredging & Kampar & 550 K.W. \\
\hline Leong Mong Chew & Kampar & 200 K.W. \\
\hline Wan Fook & Kampar & 400 K.V.A \\
\hline Hah Liew Yee & Selibin & 600 K.V A \\
\hline Chen Yoon Seong & Kampar & 300 K.W. \\
\hline Leow Yee Thong & Kampar & 650 K.V.A \\
\hline Lai Weng Huin & Papan & 300 K.W. \\
\hline Chong Foong & Pusing & 250 K.W \\
\hline Keat Hock Tong Mining Kongsi & Pusing & 600 K.V.A \\
\hline Malim Mawar Tin Ltd & Malim Mawar & 800 K.W. \\
\hline Yap Chin & Batu Gajah & 300 K.V.A. \\
\hline Lim Boon Haw & Malim Mawar & 140 K.V.A \\
\hline Tai Chee Show & Kampar & 140 K.V.A \\
\hline Anglo-Oriental (Malaya) Ltd & Tanjong Toh Alang & 7,000 K.V.A. \\
\hline Sunber C.O.717/64/62367, Perak Hydro-Electic Co., hlm. 136. \\
\hline
\end{tabular}

Sumber: C.O. 717/64/62367, Perak Hydro-Electric Co., hlm. 136.

Selain membina stesen janaelektrik, PRHEP turut menubuhkan sebuah anak syarikat iaitu Kinta Electrical Distribution Company (KED) untuk membantu menguruskan pembekalan elektrik di Perak yang semakin meningkat. Syarikat yang ditubuhkan pada tahun 1928 ini dipengerusikan oleh Col. Cecil Rae dan F.W. Palmer sebagai pengarah 
urusan.Penubuhan KED bertujuan mengagihkan bekalan elektrik yang dihasilkan oleh PRHEP kepada penduduk di kawasan pekan dan kampong yang berada dalam kawasan konsesi. Kawasan konsesi seluas 3,615 batu persegi melibatkan Daerah Kuala Kangsar bersama-sama dengan Mukim Durian Pipit, Temelong dan Lenggong; Daerah Kinta; Mukim Chenderiang, Batang Padang dan Birdo di Mukim Batang Padang; Mukim Pulau Tiga, Kampung Gajah dan Panjang Ulu. ${ }^{57}$ Berikut merupakan beberapa lagi kawasan yang mendapat bekalan elektrik dari KED untuk kegunaan kilang, lampu jalan dan domestik:

Jadual 8: Bandar yang mendapat bekalan elektrik menerusi KED

\begin{tabular}{|l|l|l|l|}
\hline Bandar & Penjanaan & $\begin{array}{l}\text { Keupayaan } \\
\text { Penjanaan }\end{array}$ & $\begin{array}{l}\text { Tarikh } \\
\text { Pembekalan }\end{array}$ \\
\hline Menglembu & PRHEP & 50 k.v.a & 30.7 .1929 \\
\hline Lahat & PRHEP & 50 k.v.a & 5.7 .1930 \\
\hline Papan & PRHEP & 50 k.v.a & 12.8 .29 \\
\hline Pusing & PRHEP & 50 k.v.a & Feb. 1929 \\
\hline Siputeh & PRHEP & 20 k.v.a & 28.11 .1935 \\
\hline Tronoh & PRHEP & 50 k.v.a & Dec. 1928 \\
\hline Tanjong Tuallang & PRHEP & 50 k.v.a & Dec. 1928 \\
\hline Gopeng & French Tekka Mines & 32 k.v.a & 1.11 .1936 \\
\hline Malim Mawar & PRHEP & - & 16.6 .1936 \\
\hline Kampar & PRHEP & 150 k.v.a & 1.8 .1929 \\
\hline Temoh & PRHEP & 50 k.v.a & Jan. 1929 \\
\hline Chenderiang & PRHEP & 50 k.v.a & Jan. 1929 \\
\hline Tapah & PRHEP & 100 k.v.a & 2.11 .1936 \\
\hline Sungei Siput & PRHEP & 50 k.v.a & 24.12 .1936 \\
\hline Chemor & Oil Engines (two) & 52 k.v.a & 25.9 .1936 \\
\hline Kuala Kangsar & Oil Engines (three) & 222 k.v.a & 10.5 .1932 \\
\hline Bagan Serai & Oil Engines & 50 k.v.a & $1937 / 1938$ \\
\hline Parit & PRHEP & - & $1937 / 1938$ \\
\hline Tanjong Rambutan & PRHEP & - & $1937 / 1938$ \\
\hline
\end{tabular}

Sumber: C.O.576/56, Annual Report and Accounts of the Electrical Department.

Syarikat Huttenbach merupakan sebuah lagi syarikat swasta yang memainkan peranan dalam menyediakan kemudahan bekalan elektrik di NNMB khususnya di Perak. Berbeza dengan PRHEP, peranan yang dimainkan oleh Syarikat Huttenbach dilihat lebih kepada pemasangan alat penjanaan elektrik dan membekalkan tenaga elektrik untuk kegunaan awam. Seawal tahun 1912, Jurutera Mekanik syarikat tersebut, F.J. Hill telah menguruskan pemasangan enjin jenis Tangyes untuk menggerakkan dynamo $1 / 2 \mathrm{~kW}$ yang disambungkan pada kipas angin di Kedai Whiteaway Laidlaw. ${ }^{58}$ Manakala pada tahun 1926 Syarikat Huttenbach telah mendapat hak untuk membekalkan elektrik di kawasan Teluk Anson, Perak. Satu perjanjian telah ditandatangani antara wakil syarikat, Sefton Cullen dengan Oswald Francis Gerald Stonor, Residen Perak pada 15 Jun 1926.Menerusi perjanjian tersebut, pihak syarikat perlu menyiapkan pemasangan peralatan membekalkan elektrik untuk kegunaan pihak kerajaan dan awam dalam tempoh enam bulan dan mula membekalkan elektrik dalam tempoh dua belas bulan dari tarikh perjanjian. Sekiranya gagal berbuat demikian, maka pihak kerajaan berhak menamatkan konsesi atau mengenakan denda sebanyak \$10 sehari untuk menyiapkan kerja pembekalan elektrik selepas tempoh yang diberikan tamat. ${ }^{59}$

Pada masa yang sama, Syarikat Huttenbach turut membuat perjanjian dengan Sanitary Board, Lower Perak yang diwakili oleh S.H. Langston. Perjanjian tersebut menyatakan pihak 
Sanitary Board memberi hak kepada Syarikat Huttenbach untuk mendirikan, memasang dan menyelenggara lampu jalan di Teluk Anson; tempoh konsesi selama 20 tahun; bayaran bulanan kepada syarikat sebanyak $\$ 12$ bagi setiap lampu berkuasa 200 c.p dan $\$ 5$ bagi lampu 50 c.p; denda yang dikenakan sekiranya pihak syarikat gagal memberikan perkhidmatan yang cekap, gagal mematuhi mana-mana bahagian dalam Electricity Enactment dan sebagainya. ${ }^{60}$ Berikutnya pada 1 Mac 1929, perjanjian ditandatangani dengan Jabatan Elektrik yang memberikan hak kepada Syarikat Huttenbach untuk melakukan kerja-kerja pendawaian di bangunan Central Mental Hospital, Tanjong Rambutan. ${ }^{61}$

United Engineers Limited merupakan sebuah lagi syarikat swasta yang memainkan peranan dalam menyediakan bekalan elektrik di NNMB khususnya di Seremban, Negeri Sembilan. ${ }^{62}$ Skim pembekalan elektrik di Seremban pada asalnya dirangka oleh jabatan elektrik PWD Kuala Lumpur sejak tahun 1912 lagi. ${ }^{63}$ Setelah itu hak untuk menguruskan pembekalan elektrik diserahkan kepada United Engineers Limited menerusi perjanjian yang ditandatangani pada Mac 1915. ${ }^{64}$ Menerusi skim tersebut, pihak United Engineers Limited dikehendaki menguruskan pembekalan elektrik untuk kegunaan bangunan kerajaan dan 250 lampu jalan (61 buah lampu berkuasa 200 c.p dan 190 buah lagi berkuasa 50 c.p). Sehingga penghujung tahun 1916, sebanyak 202 pengguna telah mendapat bekalan elektrik termasuklah 97 buah bangunan kerajaan seperti penjara, balai polis, hospital dan sebagainya. ${ }^{65}$

\section{Kesimpulan}

Berdasarkan kepada perbincangan yang dibuat dapat disimpulkan bahawa permulaan abad ke-20 sehingga tahun 1941 merupakan satu tempoh yang sangat penting dalam memperkatakan mengenai perkembangan kemudahan bekalan elektrik di NNMB. Perkhidmatan yang disediakan pada ketika itu adalah hasil usaha pihak kerajaan dan juga syarikat swasta. Kedua-dua pihak dilihat memainkan peranan tersendiri dalam menyediakan perkhidmatan dengan membina stesen janaelektrik dan menguruskan pembekalannya. Namun jika diperincikan peranan kedua-dua pihak tersebut, jelas sekali ia memberi nilai yang berbeza.Bagi pihak kerajaan, perkhidmatan yang disediakan melibatkan keempat-empat negeri. Walaupun pada peringkat awal ia hanya tertumpu di Kuala Lumpur sahaja, namun hasil usaha yang diambil kemudiannya telah membolehkan perkhidmatan disediakan di beberapa buah kawasan di setiap negeri. Bermula dengan PWD diikuti dengan Electrical Board sehinggalah penubuhan Jabatan Elektrik telah memberi gambaranakan kesungguhan pihak kerajaan untuk membangunkan perkhidmatan bekalan elektrik. Selain itu, penyediaan bekalan elektrik juga tidak hanya tertumpu kepada satu-satu sektor sahaja sebaliknya melibatkan semua aspek baik ekonomi mahupun kegunaan harian. Manakala, bagi syarikat swasta pula, perkhidmatan yang disediakan hanya tertumpu di sesebuah negeri sahaja.Misalnya, PRHEP, KED dan Huttenbachs tertumpu di Perak, RAGM di Pahang dan United Engineers Limited di Negeri Sembilan. Penyediaan bekalan elektrik juga tidak melibatkan kesemua sektor sebagaimana pihak kerajaan sebaliknya tertumpu kepada sektor tertentu seperti yang dinyatakan dalam konsesi.

\section{Nota}

C.O. 576/10, Federated Malay States: Report by the Director of Public Works Department for the year 1912, hlm. 4.

C.O. 576/28, Federated Malay States: Annual Report of the Electrical Board for the year 1924, hlm. 8. Muzaffar Tate, Power Builds The Nation: The National Electricity Board of the States of Malaya and Its Predecessors, Kuala Lumpur: The Natonal Electricity Board of the States of Malaya, 1989, hlm. 199. 
Ibid., hlm. 120.

C.O. 717/53/17997, Creation of Separate Electrical Department and Appoint of Independent Head, hlm. 6.

C.O. 576/34, Annual Report and Accounts of the Electrical Department for the year 1927, hlm. 1.

C.O. 717/53/17997, Creation of Separate Electrical Department and Appoint of Independent Head, hlm. 12-13. Muzaffar Tate, Power Builds The Nation: The National Electricity Board of the States of Malaya and Its Predecessors, hlm. 128. Sumangala Pillai, Tenaga Penggerak Kemajuan, Selangor: Tenaga Nasional Berhad, t.t., hlm. 17.

8 Muzaffar Tate, Power Builds The Nation: The National Electricity Board of the States of Malaya and Its Predecessors, hlm. 125.

9 C.O. 273/302/32532, Kuala Lumpur Lighting Scheme: Correspondence Lighting of Kuala Lumpur by Electricity, hlm. 523.

10 SSF 4648/1921, Kuala Lumpur Electricity Supply - Preliminary Report by Mr. Bolton, hlm. 2.

11 Lembaga Letrik Negara Tanah Melayu: Jubli Perak, $1 \mathrm{hb}$ September 1974, Kuala Lumpur: Jabatan Penerangan Lembaga Letrik Negara, 1974, hlm. t.h.

12 C.O. 576/10, Federated Malay States: Report by the Director of Public Works for the year 1912, hlm. 4.

13 C.O. 576/15, Federated Malay States: Report on the Public Works Department for the year 1916, hlm.

6. C.O. 576/19, Federated Malay States: Report on the Public Works Department for the year 1918, hlm. 8.

14 C.O. 576/25, Federated Malay States: Annual Report of Electrical Board for the year 1922, hlm. 1.

15 C.O. 576/26, Federated Malay States: Annual Report of the Electrical Board for the year 1923, hlm. 3.

16 Muzaffar Tate, Power Builds The Nation: The National Electricity Board of the States of Malaya and Its Predecessors, hlm. 199.

17 C.O. 576/25, Federated Malay States: Annual Report of Electrical Board for the year 1922, hlm. 2.

18 C.O. 576/26, Federated Malay States: Annual Report of the Electrical Board for the year 1923, hlm. 4.

19 Muzaffar Tate, Power Builds The Nation: The National Electricity Board of the States of Malaya and Its Predecessors, hlm. 64.

20 C.O. 576/25, Federated Malay States: Annual Report of the Electrical Board for the year 1922, hlm. 3.

21 C.O. 576/28, Federated Malay States: Annual Report of the Electrical Board for the year 1924, hlm. 8.

22 C.O. 576/30, Federated Malay States: Annual Report of the Electrical Board for the year 1925, hlm. 11.

23 C.O. 717/94/13318, Sungei Besi Purchase of Hydro-Electric Plant, hlm. 33. Walter Fitzpatrick,

"Zaman Kegemilangan Saya", dalam Noraini Abd Murad (penyunting), Wajah-wajah Di Sebalik

Cahaya, Kuala Lumpur: Lembaga Letrik Negara Tanah Melayu, 1988, hlm. 114.

24 C.O. 576/41, Federated Malay States: Annual Report and Accounts of the Electrical Department for the year 1930, hlm. 28.

25 C.O. 576/44, Federated Malay States: Annual Report and Accounts of the Electrical Department for the year 1931, hlm. 32-33.

26 Annual Report on the Social and Economic Progress of the Pahang, 1935, hlm. 54.

27 C.O. 576/39, Federated Malay States: Annual Report and Accounts of the Electrical Department for the year 1929, hlm. 27.

28 Ibid., hlm. 28.

29 C.O. 576/44, Federated Malay States: Annual Report and Accounts of the Electrical Department for the year 1931, hlm. 30 .

30 C.O. 576/46, Federated Malay States: Annual Report and Accounts of the Electrical Department for the year 1932, hlm. 49.

31 C.O. 576/69, Federated Malay States: Annual Report and Accounts of the Electrical Department for the year 1939, hlm. 33 .

32 Ibid., hlm. 33-34.

33 SSF 2867/1928, Electricity as a Motive Power for Operation of Dredges.

34 C.O. 576/36, Federated Malay States: Annual Report and Accounts of the Electrical Department for the year 1928, hlm. 6.

35 C.O. 576/44, Federated Malay States: Annual Report and Accounts of the Electrical Department for the year 1931, hlm. 5 .

36 C.O. 576/50, Federated Malay States: Annual Report and Accounts of the Electrical Department for the year 1934, hlm. 12. C.O. 576/53, Federated Malay States: Annual Report and Accounts of the Electrical Department for the year 1935, hlm. 20.

37 A.B. Voules, The Laws of the Federated Malay States, 1877-1920 (Vol. II), London: Hazell, Watson \& Viney, 1921, hlm. 528.

$38 \quad$ Ibid., hlm. 530. 
Ibid., hlm. 535.

Ibid.

Ibid., hlm. 530.

SSF (G), 244/1937, Private Installation of Electricity by Ying Nam Tin Mine, Salak South, Selangor.

SSF (G), 300/1937, Private Installation of Electricity by Ban Sin Kongsi.

C.O. 576/32, Federated Malay States: Annual Report and Accounts of the Electrical Department for the year 1926, hlm. 9.

A.B. Voules, The Laws of the Federated Malay States, 1877-1920 (Vol. II), hlm. 535.

E.R. Weerasingham Lee, "Dari Diesel Membawa Ke Stim", dalam Noraini Abd Murad (penyunting), Wajah-wajah Di Sebalik Cahaya, Kuala Lumpur: Lembaga Letrik Negara Tanah Melayu, 1988, hlm. 177. C.O. 717/73, Raja Zainal Course in Electrical Engineering. Raja Tan Sri Zainal bin Raja Sulaiman, "Zaman Peralihan", dalam Noraini Abd Murad (penyunting), Wajah-wajah Di Sebalik Cahaya, Kuala Lumpur: Lembaga Letrik Negara Tanah Melayu, 1988, hlm. 57. Ismail Azman Omar, Raja Zainal Raja Sulaiman: Peneraju Lembaga Letrik Negara, Kuala Lumpur: Dewan Bahasa \& Pustaka, 1999, hlm. 910.

Tan Sri Dato' Abu Zarim bin Haji Omar, "Dekad Pembangunan”, dalam Noraini Abd Murad (penyunting), Wajah-wajah Di Sebalik Cahaya, Kuala Lumpur : Lembaga Letrik Negara Tanah Melayu, 1988, hlm. 67. Tengku Daud bin Tengku Besar Burhanuddin, "Peperangan dan Manusia", dalam Noraini Abd Murad (penyunting), Wajah-wajah Di Sebalik Cahaya, Kuala Lumpur : Lembaga Letrik Negara Tanah Melayu, 1988, hlm. 104.

C.G. Warnford Lock, Mining in Malaya for Gold and Tin, London: Crowther and Goodman, 1907, hlm. 67-87.

Sivachandralingam Sundara Raja, "Sejarah Perlombongan Emas di Pahang : Dengan Rujukan Khas Syarikat Lombong Emas Australia Raub, 1892-1960”, dalam Malaysia Dari Segi Sejarah, Bil. 29, 2001, hlm. 120-121.

C.O. 576/32, Federated Malay States: Annual Report and Accounts of the Electrical Department for the year 1926, hlm. 1.

C.O. 717/65/62367/C, Perak River Hydro-Electric Company, hlm. 8.

Bo Manne Hellstrom, The Perak River Hydro-Electric Power Scheme, London: Great George Street, Westminister, 1934, hlm. 62.

S. Murugiah, "Chenderoh Dalam Peredaran Zaman", dalam Noraini Abd Murad (penyunting), Wajahwajah Di Sebalik Cahaya, Kuala Lumpur : Lembaga Letrik Negara Tanah Melayu, 1988, hlm. 147-148 Bo Manne Hellstrom, The Perak River Hydro-Electric Power Scheme, hlm. 62.

Bunny Khoo, "Kisah Stesen Janaelektrik Malim Mawar", dalam Noraini Abd Murad (penyunting), Wajah-wajah Di Sebalik Cahaya, Kuala Lumpur : Lembaga Letrik Negara Tanah Melayu, 1988, hlm. 132.

C.O. 717/65/62367/C, Perak River Hydro-Electric Company, hlm. 3.

S.L. Low, "Kenang-kenangan Huttenbachs Berhad", dalam Noraini Abd Murad (penyunting), Wajahwajah Di Sebalik Cahaya, Kuala Lumpur : Lembaga Letrik Negara Tanah Melayu, hlm. 140-141.

SSF. 3403/1926, From of Agreement between Huttenbach, Lazarus and Sons Limited and the Resident of Perak for Supply of Electricity to Small Town in Perak: Agreement to Grant a Licence for a Public Installation under the Electricity Enactment, 1925, hlm. 1-2.

Ibid., hlm. 1-4.

C.O. 576/39, Federated Malay States: Annual Report and Accounts of the Electrical Department for the year 1929 , hlm. 15.

C.O. 576/14, Federated Malay States: Report on the Public Works Department for the year 1915, hlm. 6.

C.O. 576/10, Federated Malay States: Report by the Director of Public Works Department for the year 1912, hlm. 4.

C.O. 576/14, Report on the Public Works Department for the year 1915, hlm. 6.

C.O. 576/15, Federated Malay States: Report on the Public Works Department for the year 1916, hlm. 6. 